\title{
Ego is a Hurdle in Second Language Learning: A Contrastive Study between Adults and Children
}

\author{
Shumaila Abdullah \\ Department of English Literature \& Linguistics \\ University of Baluchistan, Quetta, Pakistan \\ E-mail: Shumaila_abdullah914@yahoo.com \\ Javed Akhter (Corresponding author) \\ Department of English Literature \& linguistics \\ University of Baluchistan, Quetta, Pakistan \\ E-mail: sangatjavedakhtar@gmail.com
}

Doi:10.7575/aiac.alls.v.6n.6p. 170

Received: 22/07/2015

URL: http://dx.doi.org/10.7575/aiac.alls.v.6n.6p.170

Accepted: 30/09/2015

\begin{abstract}
The aim of this research paper is to find out by comparing and contrasting between the adults and children in second language learning process how language ego of adult learners affects them to learn second language, and how it becomes a barrier for them in second language learning process. Nowadays learning English as foreign and second language is one of the most dominant socio-cultural requirements of people for seeking employment, foreign tour, business, education and other basic communicative purposes. Therefore, English as foreign and second language is definitely necessary for everybody because it is one of the most urgent socio-cultural pre-requisites of the Post-modern era. It is commonly observed during teaching and learning English as a foreign language in Pakistan, that language ego hinders the adults to learn it properly. Therefore, children are more successful L2 learners than the adults are. Children learning L2 use to reproduce construction process just as they do in their L1 learning and they have the ability to cognize and reproduce new and novel utterances. The compare and contrast between adult and child second language learner will be highlighted in this research paper, which may be helpful for teachers, researchers and scholars on the subject.
\end{abstract}

Keywords: Second Language Learning Process, Adult Learner, Child Learner, Language Ego, Critical Period and Puberty Period

\section{Introduction}

The Importance of a language as the only source of communication cannot be denied in any human society of the world. Pakistan is a multilingual country where Urdu language is a lingua franca. It is not only spoken language in Pakistan but also a medium of education. In addition, a large number of people cannot communicate in Urdu language or even understand it in the various regions of the country. There are about 72 national languages spoken in the different areas of Pakistan. English language has been a constitutional language of Pakistan since 1971. It is also official language and medium of education and instruction. It is frequently used in educational institutions as a medium of instruction and offices as an official language. Therefore, English language has its own importance as an international language in this regard. Moreover, learning of English language is actually a need and demand of time.

However, English has been learned as second or foreign language in Pakistan. Nevertheless, Learning of English as second or foreign language is by no means an easy task but it is very complex process in multilingual country as Pakistan. However, it is commonly observed that a child is more successful L2 learner as compare to an adult. He is not only successful in learning a second language but also third or more and this ratio decreases with the age, as after 12 years of age to which the linguists terms critical age, the learning becomes slow because of ego. In the learning process, a school or English language classroom plays a vital role where facilitators encourage a child at every step to boost up his self-confidence. A child does not care of committing mistakes of grammar, accent and spelling so that he may definitely learn second language without any shyness, ego and hesitation. There is no trace of emotional interference in child's mind that develops with increasing of the age. Therefore, the ratio of learning a second language in children is higher. That is why children might have some secrets of success in language learning as they are not analysing and monitoring themselves too much. Moreover, they are not analysing the strict grammatical rules and regulations, and they do not allow their native language to interfere in their process of second language learning. It is much and most important factor of all. Children are not being too worried about their egos. Because they use a creative process of construction in second language learning just as they do so in acquiring their first language. However, age is a major factor determining success in learning a second or foreign language. Children are capable of acquiring second language rapidly with little effort. They can become highly proficient, even native-like speakers of second language. 
Whereas, in the case of adult second language learners, who crossed the premises of critical period and reached the boundary of puberty period, second language learning process becomes comparatively slow. The critical period hypothesis (CPH) as proposed by Lenneberg (1967) opines that primary language acquisition must occur during a critical period that ends at about the age of puberty with the establishment of cerebral lateralization of function. A strong implication of $\mathrm{CPH}$ is that the processes involving in any language acquisition, which takes place after the age of puberty, will be qualitatively different from those involved in first language acquisition. A commonly drawn, though not necessary, corollary of $\mathrm{CPH}$ is that any language learning that takes place after the age of puberty will be slower and less successful than normal first language learning (Krashen, 1975, Lenneberg, 1967, 1969 and Scovel, 1969). Adult second language learners are indeed less likely than young children to master second language are. They are doomed to failure. In this sense, it can easily be observed that their second language learning ability is affected badly. Therefore, language ego is one of the major factors that hinder the adults to learn a second language. It does not mean that language ego is only one specific factor to hamper second language learning. In addition, many other factors hamper a person to learn second language. However, the most dominate factors in this regard, is ego, which generates powerful feelings in the mind of adult that hamper or makes the learning process slower and slower. For this reason, adults are not as successful L2 learners as children are because more they think little they speak. They are actually afraid of speaking as they think that people might make fun of them if they will not pronounce the words correctly, make grammatical mistakes. If fluency will not be there the people would crack jokes on them, what if they did not answer well That is why, ego raises such questions in the mind of an adult L 2 learner and that is how it slowdowns the learning process and proves that he is not getting fruitful results.

Nevertheless, children have no such feelings. They do not care of what are they going to speak and how they are going to speak and what the others are going to think about them. They learn without any hesitation and that is why they learn and master a second language more easily and affectively rather than adult L 2 learners. According to Harley, children, learn languages better than adults do (Haley, B., 1986, p. 4). The great advantage of children is their mental flexibility to learn languages, which adults are lacking. Therefore, children produce native like-accent in second language learning. This is a great hindrance in case of adults to produce native like- accent in second language learning. As H. D Brown observes, "Children who acquire a second language after the age of five may have a physical advantage in the phonemic control of second language is physically possible yet that mysterious plasticity is still present. It is no wonder that children acquire authentic pronunciation while adults generally do not, since pronunciation involves the control of so many muscles" (Brown, H.D., 1994, p. 5). Thus, the involvement of language ego has come to influence badly and negatively in second language learning process. It makes the development of language learning skill impossible in adults. It curbs the language competence, proficiency, fluency and accuracy in adult second language learners. For this reason, mostly the adult second language learners are afraid or stressed when using the language in oral way while on the other hand a child learner never feel stressed and for the very same reason he learns in no time because of lacking language ego.

\section{Literature Review}

Language ego is a dominant factor, which influences the second language learning process of adult second language learners in our country. There is a lot of material on the subject. "Intercultural Competence in Young Language Learners: a case study" Thesis by Robyn A. Moloney submitted in partial fulfilment of the degree of Doctor of Education, at the University of Sydney, September 2007, is a brilliant study on the subject, which proves logically that young children are interculturally competent learners rather than the adults. Aladdin Assaiqeli wrote a research paper entitled "Theories of language learning: A contrasting view" in which he discussed many theories of language learning but touched the issue of language ego slightly. The critical hypothesis (CPH) as proposed by Lenneberg (1967), opines that primary language acquisition must occur during a critical period that ends at about the age of puberty with the establishment of cerebral lateralization of function. Any language learning after the age of puberty will be slower and less successful than normal first language learning (Krashen 1975, Lenneberg 1967, Scovel 1969). Children are superior to adults in acquiring the sounds of L2 (Asher, J. \& Garcia, R, 1969; Olson \& Samuels, 1973; Seliger, Krashen, \& Ladefoged, 1975; Oyama, 1976; Snow \& Hoefnagel-Hohle, 1977). Krashen, Scarcella \& Long wrote a lot on childadult differences in learning second language acquisition. (Krashen, Scarcella \& Long, 1982). The present research tends to highlight the compare and contrast between adults and children in second language learning in the light of brilliant language learning theories of these linguists to prove that language ego is a great hindrance and hurdle in the adult second language learners to learn second language.

\section{Discussion and Debate}

In fact, Language learning is a "logical problem", as formulated by Chomsky, has for centuries baffled and intrigued linguists, researchers, and language teachers and practitioners everywhere in the world. Different explanatory proposals and various theories have been expounded in endeavours to account for this marvellous human phenomenon, and indeed "the greatest intellectual feat anyone of us is ever required to perform" (Bloomfield, 1933 cited in Fromkin and Rodman, 1998:, p. 317). However, language is deeply rooted in the socio-cultural ethos of social formation in which human behaviour is formed in a specific psychological form. Moreover, second language Learning is a pre-requisite of the socio-economic conditions of Pakistani society. One cannot deny this fact that English is one of the international languages of the world, second language in many countries and foreign language in Pakistan and other countries of the world. Therefore, learning of English as a second and foreign language is a demand of education, science, technology and business of Post-modern era. Its frequent use in the offices, educational institutions, business hubs and for other 
communicative purposes in Pakistan makes it more essential to learn. That is why a large number of public and private schools are not only emphasizing and claiming to learn English as a second or foreign language but also putting all their efforts to get the fruitful results and English is being taught as main compulsory subject in Pakistan from primary to higher education level. Therefore, learning a language is definitely an art. Children are considered to be naturally gifted artists, who learn English as a second language within no time but when the critical period ends and the puberty period starts they begin to develop psychological and emotional interference, shyness, hesitation, anxiety and ego in their behaviour, so they become slower in their second language learning process. Brown describes that language ego can be damaging to language learning as follows:

"At, these inhibitions are heightened in the trauma of undergoing critical physical, cognitive and emotional changes. Their egos are affected not only in how they understand themselves, but also on how they reach out beyond themselves, how they relate to others socially, and how they use the communicative process to bring on affective equilibrium" (Brown, H. D., 1994, p. 70).

Thus, language ego is one of the psychological interferences that hinders and causes handicap in adults to learn second language. Guiora (1972) was the first linguist, who discovered the notion of language ego, claiming that this agent occurs when the learner is aware of the limitations and boundaries of a language. Therefore, language ego refers to the very personal nature of New Language Learning and is associated with the fear of making mistakes. These mistakes work as internal and external threats to one's ego. Ego boundaries, according to M. E. Ehrman, "are the degree to which individuals tend to compartmentalize their experience, which effects receptivity to outside influences such as new languages and cultures. Learners, like others, try to build set of defences to protect the ego. In classroom, students' learning preferences depend on how thick or thin their ego boundaries are, Students with thin ego enjoy content-based learning where the focus is on what is being said more than how it is said. Many of them prefer non-linear approaches to learning and enjoy unexpected learning events. Students with thick ego boundaries, on the other hand, prefer a clearly structured curriculum and display some discomfort with role-playing and similar suspenses of everyday identity" (Ehrman, M. E. 1999, p. 69).

On the contrary, a child learns a new language in the same way, as he is least bothered about the limitations and boundaries just as an adult second language learner has produced in his mind. Children develop knowledge through active participation in their learning process. Their cognitive development is a product of mind "achieved through observation and experimentation" (Chambliss, J.J, 1996). However, second Language learning requires social interaction and without interacting socially, it is not possible to learn second language. For the very same reason children learn more actively and efficiently a second language as they are not ruled by their ego. They are confident, bold, frank enough, and not afraid of interacting with the others. However, an adult second language learner feels hesitant, stressed and sometimes afraid of the people resulting in failure or most of the time these barriers make him slower and handicap second language learner. Language ego is one of the most effective elements that interfere with the adult' oral production and grammatical syntax in the second language learning and personal and emotional factors are outcome of that ego which affects the learning in adults. Age difference is of great importance in second language learning. It largely determines the extent to which the second language learner retains the faculties that made it possible for him to learn his first language. Therefore, children learn languages quickly and better than adults do. According to Harley, children, learn languages better than adults do (Haley, 1986, p. 4). The great advantage of children is their mental flexibility to learn languages, which adults are lacking. Therefore, children produce native like-accent in second language learning. This is a great hindrance in case of adults to produce native like- accent in second language learning. As H. D Brown observes:

"Children who acquire a second language after the age of five may have a physical advantage in the phonemic control of second language is physically possible yet that mysterious plasticity is still present. It is no wonder that children acquire authentic pronunciation while adults generally do not, since pronunciation involves the control of so many muscles" (Brown, H.D., 1994, p.51).

On the contrary, self-confidence is an important element of second language learning process if a person really wants to achieve something. Being confident means let one go ego, accept the new challenges and to leave behind all egoist feelings, thoughts and flaws in the personality. As Brown defines self-confidence as "The belief that learner has that he is capable of doing a task, which is a factor in the success of attaining the task" (Brown, 2001, p. 62). In this manner, age is the strongest predictor of second language learning. Therefore, children are considered the most proficient learners of L2 than adults. They learn and learn, no matter what. Children are not afraid of taking risks and this quality lacks in the adult learners due to their language ego that force them to speak fluently, accurately and without committing a single grammatical mistake. Therefore, they prefer to remain quiet in the presence of others. They complain that they were demotivated when people show negative attitude towards their language performance. Therefore, they would be unsuccessful L2 learners if they utter anything incorrect and do not learn lesson from their mistakes. On the contrary, children might have some extraordinary linguistic power, possessing the secrets of language learning. These aspects cannot be denied that they learn more effectively than the adult learners as they are not afraid of committing linguistic mistakes, they do not monitor themselves as the adults do, they are not analysing their grammar, not letting the native language interfere much and most important of all not being too worried about their egos.

In fact, language input is also as important factor in the process of second language learning in which learner learns second language as it is to the first language learner. However, teacher input might do well to be as deliberate, but meaningful, in their communications with adult students as parental input to the child. Therefore, the role of input is 
undoubtedly very important in this respect. Krashen has put forward the input hypothesis that reveals the importance he places on input. Input by the teacher can really be helpful to reduce egoist feelings of an adult learner, having somewhere in the mind so that that may not be deep rooted in their personalities. Therefore, comprehensive input is always required in second language learning. Children learning L2 use in a productive construction process just as they do in their L1 learning and they have the ability to cognize and reproduce new and novel utterances. Adult learner lacks this quality. In fact, a great difference between adults and children is an innate disposition. An infant learns second language in a way as he acquires his native language. On the contrary, an adult second language learner fails to do so because he reaches the height of developmental stage of his personality, in which he enters into a new zone of monitoring his linguistic mistakes where his ego rules him.

\section{Conclusion}

This research study tried to prove the importance of learning English as a second language, which is one of the sociocultural pre-requites of Post-modern era, in which we live. Therefore, a contrastive comparison is conducted between a child and an adult second learner, which clearly declares that a child is more proficient and successful L2 learner as compare to an adult. His skill of second language learning is affected when he crosses the borders of critical period and enters the premises of puberty period where he starts to develop psychological and emotional feelings as language ego, anxiety, hesitation and shyness. There are many reasons behind that and ego is one of the most important factors that hinder the ability of second language learning in adults. Thus, age is the strongest predictor in the process of second language learning. The more number of cases of the post-pubertal subjects with slower language proficiency may be found around us, which make it easy to draw a general conclusion that the post-pubertal second language learning is greatly affected by language ego.

However, numerous efforts can be made to bring the positive changes in the behaviour of adult L2 learners while learning English as a second language in English language class. It could be in the form of input, by giving them selfconfidence and not highlighting their mistakes in the presence of the others in classroom. Therefore, one must let go the false beliefs and baseless assumptions that form the language ego in adult second language learners and damages their personality. As a result, the present study suggests the solution of this problem, that motivation of teacher and classmates, aptitude of adult second language learners, ways of instructions and teaching methodology of the learned and motivated teacher as well as classroom atmosphere may prove helpful for adult second language learners to learn second language in the classroom. If these steps will be taken, they are helpful for adult second language learners to overcome their language ego.

\section{References}

Aladdin, A. (2013). Theories of language learning: A contrasting view. Scholarly Journal of Scientific Research and Essay (SJSRE, 2(3), pp. 34-43, March 2013 Available online at http:// www.scholarly-journals.com/SJSRE ISSN 23156163 (C) 2013 Scholarly-Journals.

Asher, J. \& Garcia, R. (1969). The optimal age to learn a foreign language. Modern Language Journal 53, pp. $334-342$. Brown, H. D. (1994). Principles of Language Learning Teaching. New Jersey: Prentice Hall.

Brown, H. D. (2001). Teaching by Principles: An Interactive Approach to Language Pedagogy. New York: Pearson Longman.

Chambliss, J.J. (1996). Philosophy of Education: An Encyclopaedia. New York and London: Garland Publishing Company.

Ehrman, M. E. (1999). "Ego boundaries and tolerance of ambiguity in second language learning": In Arnold, J. (ed.), Affect in Language Learning. Cambridge: CUP (P. 68-86).

Fromkin, V., Rodman, R. (1998). An Introduction to Language (6th edn.). USA: Rinehart and Winston.

Harley, B. (1986). Age in Second Language Acquisition. England: Multilingual Matters Ltd., Lightbown, P.M. and Spada, N. (1999). How Languages Are Learned. Oxford: Oxford University Press.

Krashen, S. (1975). The critical period for language acquisition and its possible bases. In D. Aaronson \& R. W. Rieber (eds.), Development psycholinguistics and communication disorders. New York: New York Academy of Sciences.

Lenneberg, E. (1967). Biological foundation of language. New York: Wiley

Moloney, Robyn A. (2007). Intercultural Competence in Young Language Learners: a case study. Thesis submitted in partial fulfilment of the degree of Doctor of Education, at the University of Sydney, September 2007.

Olson, L. \& Samuels, S. (1973). The Relationship between age and accuracy of foreign language pronunciation. Journal of Educational Research, 66, pp. 263-268.

Oyama, S. (1976). A sensitive period for acquisition of a non-native phonological system. Journal of Psycholinguistic Review, 5, pp. 261-284.

Scovel, T. (1969). Foreign accents, language acquisition and cerebral dominance. Language Learning, 19, pp. $245-253$. Seliger, H.W., Krashen, S.D., \& Ladefoged, P. (1975). Maturation consonants in the acquisition of second language accent. Language Sciences, 36, pp. 20-22.

Snow, C., Hoefnagel-Hohle, M. (1977). Age Differences in the pronunciation of foreign sounds. Language and Speech, 20, pp. 357-365. 